\title{
Újabb kutatás a kaposszentjakabi apátság területén 1.
}

\author{
MOLNÁR ISTVÁN \\ Rippl-Rónai Megyei Hatókörü Városi Múzeum, H-7400 Kaposvár, Fő u. 101., \\ e-mail: molnaristvan74@yahoo.com
}

MolnÁR, I.: Research in the area of the Benedictine abbey, Kaposszentjakab Part 1.

Abstract: The paper deals with the abbey founded in the 11 . Century, with its periods and remains of an earlier building.

Keywords: Middle age, Benedictine abbey, cemetery, fortifications

Térségünk egyik legszebb és legfontosabb műemléke a kaposszentjakabi bencés monostor romterülete. Az 1061-ben alapított, egykor Zselicszentjakabinak hívott apátság, hazánk első ismert magánalapítású bencés monostora. A kolostori templom viszonylag magasan fennmaradt falai 11. századi építészetünk legfontosabb emlékei közé tartoznak. Az itt talált, részben a 11. századra keltezhető kőanyag müvészettörténetünk fontos forrása. Nagy Emese vezetésével immár fél évszázada feltárt épületek eredeti formájának rekonstruálása régóta foglalkoztatja a kutatást. Tanulmányom megírásával ehhez a munkához kívántam hozzájárulni. Nagy Emese és munkatársai által készített dokumentáció néhány a templomra vonatkozó fontos megállapításának, rajzának, fotójának közlése mellett eredetileg a 2013. őszén, 3 kis területen végzett hitelesítő feltárás eredményeinek rövid ismertetését terveztem. A kézirat lezárása előtt azonban újabb munkákat végezhettünk az apátság területén, ami során gyakorlatilag a teljes templomot és egy ahhoz délkeletröl csatlakozó kisebb területet sikerült (újra) feltárni. Bár a dokumentáció végleges elkészítése, a leletanyag feldolgozása és az anyagvizsgálatok elvégzése előtt korai lenne végleges következtetéseket levonni, a feltárás legfontosabb eredményeiről is szeretnék röviden beszámolni.

\section{A kolostor és temploma}

A ma már Kaposvárhoz tartozó, a mai városközponttól keletre található apátság az erdős Zselicség és a Kaposvölgy találkozásánál épült. A magas dombon fekvő épületegyüttes az egykor széles árterü Kapos folyóra nézett, a víz túloldalán a középkorban is út futott, amely mellett falvak feküdtek. ${ }^{1}$ (1. ábra)

1 Az egykori falvak közül többet sikerült régészetileg azonosítani. $A z$ apátsággal szemben fekvő, Keszi faluval azonosított település templomát és temetöjét Bárdos Edith vezetésével tárták fel. (Bárdos 1978., Bárdos 1987.) Az ettől 2 km-re nyugatra lévő település néhány későközépkori objektumát 2010-ben, közmüvezeték ásásakor találtuk meg és tártuk fel.

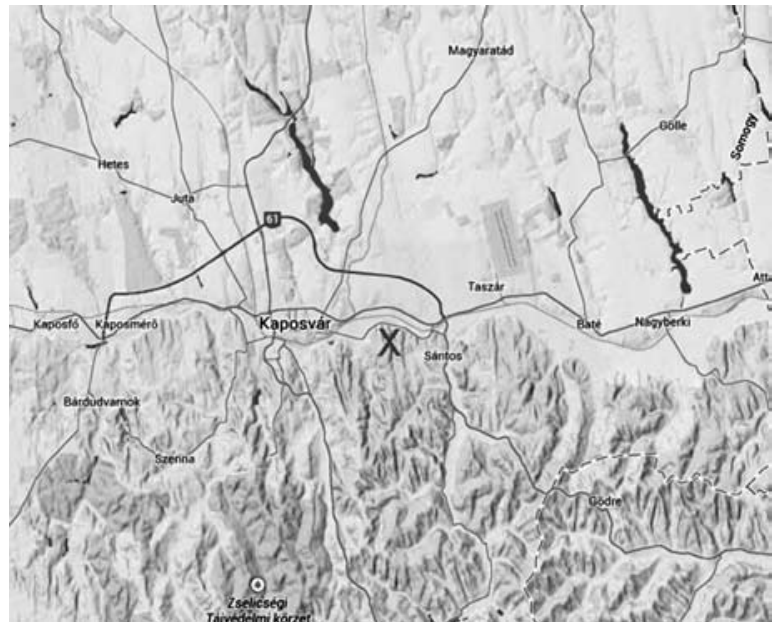

1. ábra: Az apátság elhelyezkedése

A kolostor alapításának körülményeit viszonylag jól ismerjük, az alapítólevél szövegének másolatát egy későbbi, 1432-es oklevélben fedezte fel Kumarovitz Bernát. ${ }^{2}$ A Győr nembeli Atha (Ottó) nádor és somogyi ispán Szent Jakab hegyén alapította monostorát, ahol korábban már volt egy, az említett szentnek szentelt templom, amely „szerfölött régisége és elhanyagoltsága miatt már pusztán állt". A domb lakott volt, az itt élőket az alapító elköltöztette. A kolostor közvetlen birtokát a Lápa és a Kapos összefolyása illetve a Nádasdi völgy nyugati pereme határolta, itt volt a török-korig létező Szentjakab falu is. Ezzel a területtel az apátság 9 ekealja földet, valamint szántó-vetőket, szolgákat, szőlőműveseket, fafaragót, molnárt, kanászt, marhapásztort kapott, a vagyonát megalapozó jelentős birtokadományok nagy területen elszórva feküdtek. Az alapítás után néhány év alatt felépült a kolostor temploma, amelynek a dalmáciai hadjáratról hazatérő Salamon király és Géza herceg jelenlétében végzett felszentelése nagy esemény volt, a Képes Krónika is megemlékezik róla. ${ }^{3}$

$\mathrm{Az}$ apátságnak több mint 60 helységben voltak birtokai, a földek mellett templomok, kápolnák, udvarházak, vámok is tartoztak hozzá, ugyanakkor a kegyúri család erős befolyása erősen korlátozta ezt a gazdagságot. A Győr nemzetség tagjai 1329-ben megegyeztek, hogy a jövedelem harmada a kolostoré, a többi egyenlően oszlik meg a család két ága között.

$2 \quad$ Kumarovitz 1964.

3 Képes Krónika 99. 


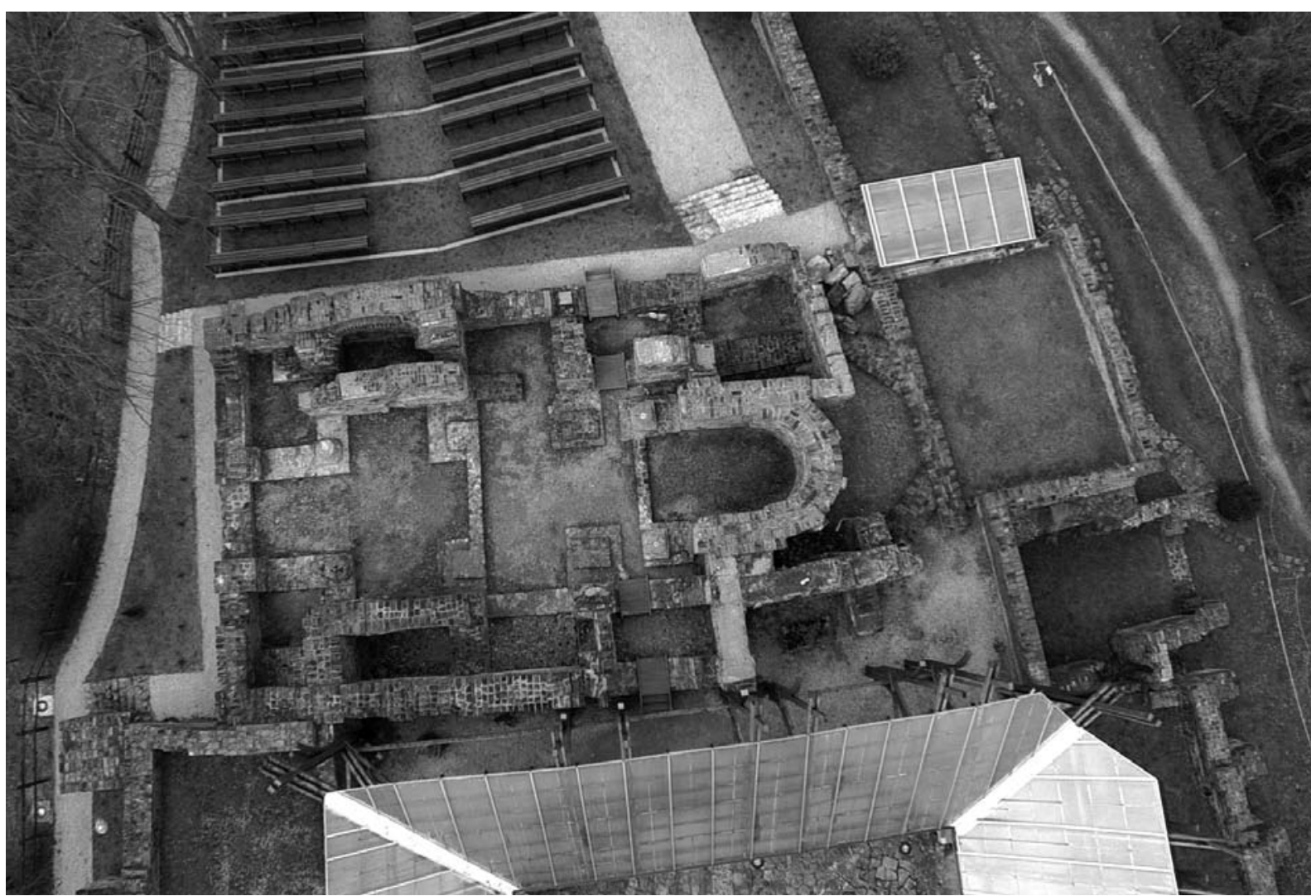

2. ábra: Légifotó az apátsági templom romjairól (Pazirik Kft)

A későbbiekben is folyamatosak a perek, sőt erőszakos konfliktusok, amelyben a kegyúri nemzetség különböző ágai állnak szemben egymással illetve a kolostorral. Leginkább a Szerdahelyi Dersfiek voltak az apátság kegyurai, általában apátokat is ők állítottak. 1392-ben búcsúengedélyt kapott a kolostor. Az 1508as bencés vizitációból tudjuk, hogy az apáttal együtt 6 szerzetes élt az apátságban. Ekkor az épület jó állapotban volt, csak a szolgák nagy számát kifogásolták. 1543-ban a szerzetesek elhagyták a kolostort, katonák érkeztek helyükre. Az épületegyüttes Kaposvárral együtt török kézbe került. ${ }^{4}$

A feltárások 1960 és 1966 között Nagy Emese vezetésével zajlottak. Az itt dolgozók hatalmas munkát végeztek: a korábban gyakorlatilag föld alatt lévő, helyenként több méter magas romokat kiásták, nagyszámú sírt és igen értékes kőanyagot tártak fel, lehetőség szerint tisztázták a templom és a kolostori épültek alaprajzát és időrendjét. Több építési periódust elkülönítettek, egyértelművé vált egy gótikus átépítés ténye és egy az apátságnál korábbi, az alapítólevélben említett templomra utaló nyomokat is találtak.

Ugyanakkor a kolostorral és templomával kapcsolatban számos kérdés megválaszolásra vár. Ennek részben az az oka, hogy csak egy rövidebb beszámoló

4 A kolostor történetéröl bővebben: Zádor 1964. 28-37., 45-48., Györffy 1975. 66-67, Komjáthy 1975. 75-76., Magyar 1981. 3-8., Hervay 2001. 527., Aradi 2007. adattár jelent meg a feltárás eredményeiröl, ez mindössze 2 oldal szöveget valamint 1 oldalnyi képet és egy alaprajzot tartalmazott. ${ }^{5}$ Később a feltárást vezető régész még két kiállítás-katalógusban írt röviden az épületekről. ${ }^{6} \mathrm{Az}$ ásatási dokumentáció a múzeumunkban is fellelhető, ${ }^{7}$ de az egykor készített és elöhívott fekete-fehér fotók ma már nem mindig kellően informatívak. Sajnos a dokumentáció nem terjedt ki az alapozás teljes dokumentálására, annak csak egyes részeit rajzolták, fotózták le. A publikációban közölt térkép sem teljes, az álló falakra koncentrál, több, alapjaiban létező, de föld felé már nem menő fal nincs rajta ábrázolva. Azóta ezt az alaprajzot vették át több tanulmányba és úgy tünik, többen ez alapján próbálták az egykori templomot rekonstruálni. A Zádor Mihály által vezetett müemléki helyreállításkor többnyire a csak alapjaikban létező falakat is jelölték, így ezek viszonylag jól követhetőek a Pazirik Kft által 2014-ben készített légifotón (2. ábra) A helyreállítás gyakorlatilag a feltárással együtt folyt, talán ez is nehezítette a megfigyelt jelenségek pontos kiértékelését. Az apátsági templom különleges szerkezete mellett, talán az említett nehézségekkel is magyarázható, hogy az elmúlt évtizedekben a templom rekonstruálására több erősen eltérő megoldás is született a szakirodalomban.

$5 \quad$ Nagy 1973. 335-339.

6 Nagy 1978. 90, Nagy 1994. 71-72

7 A Rippl-Rónai Városi Hatókörű Városi Múzeum (korábban SMMI) adattára 662-666. 


\section{Az apátsági templom rekonstruálásával kapcsola- tos elképzelések}

A régészeti feltárás eredményeinek első részletesebb ismertetése érdekes módon nem az ásatást vezető régész, hanem a helyreállítási terveket készítő Zádor Mihály nevéhez füződik, akinek még a feltárás folyamán jelent meg a Kaposvár című könyve. Ebben igen érdekes, látszólag háromhajós, egyapszisos templomról beszél, ahol a dongaboltozatos keskeny „mellékhajók” (így idézőjelbe téve) egyes szakaszai fallal vannak elválasztva a föhajótól. Véleménye szerint ezek a „mellékhajók" szertartási-előkészületi célokat szolgáltak, illetve a donátorok temetkezési helyei voltak. Azt írta a kegyúri karzatot tartó két pillér alapja és az arra vezető lépcső indítása is feltárásra került. A korábbi templomot, az alapítólevélben említett „szerfölött régisége és elhanyagoltsága" miatt, nem tartotta 11. századinak. Az államalapítás előtti szláv templomot, de inkább az itt talált római maradványokat, illetve ezekböl összetákolt épületet feltételezett. $A$ templom gótikus átépítését és a kolostornégyszög kiépítését a 14-15. századra tette. A munkákat részben az 1392-es búcsúengedélyhez kötötte, de feltételezett egy 15 . század közepére, második felére tehető építési időszakot is. A templomtól északra lévő centrális kápolnát késő középkorinak gondolta. ${ }^{8}$

1973-ban jelent meg Nagy Emese beszámolója, amelyben a feltárás vezetője röviden összefoglalta az apátság történetét és bemutatta a feltárt maradványokat. Közölt egy alaprajzot is. A templomról megállapította, hogy a most romjaiban látható épület az alapítás után épült, így a legrégebbi része a kolostornak. Félköríves, kiugró apszissal záródó föhajót, keskeny oldalhajókat rekonstruált, amelyhez oldalról nagy, részben zárt és boltozott karzatlépcső alapozások és egyéb térelválasztó elemek csatlakoznak. Hangsúlyozta, hogy a mellékhajókat elválasztó oszlopsorok feltűnően masszív alapozásai egyenlőtlen távolságokra vannak, az apszis mellett in situ megtalált oszloplábazatok faragottak. A közölt alaprajzon is érzékeltette az alapozások méretbeli különbségét. A kolostornégyszög teljes kiépítését, valamint a templom gótikus átépítését a 14-15. század fordulójára tette és egy 1387-töl tartó békésebb időszakhoz kötötte, amikor nem folytak harcok a kegyuraságért. Azt írta, a kolostor korábbi, a szabályos kolostornégyzet kialakulását megelőző szerkezetét nem lehetett pontosan megismerni a feltárás során. Mindenképpen eltért a szokásos kolostorsémától, fallal vették körül, amire részben ráépültek az újabb épületek. A keleti szárny északi vége előtt nagyméretű pincét alakítottak ki, a kolostorépület külső falait nagy támpillérekkel erősítették, amely a meredek domboldalon épült épület falait óvta a megcsúszástól és a későbbi időszakban védfalként is szolgált. A délkeleti sarok megcsúszásával magyarázta az itteni többszöri átépítést is. Egy külső, feltáratlan védőfalat is említett a keleti zárófalon kívül. Úgy gondolta, a keleti kolostoroldal templomtól észak-

8 Zádor 1964. 28-37., 45-48. ra lévő része már nem volt használatban a késői időszakban. A kolostortól északra álló, nyolcszög alakú hajóból és nyolcszög öt oldalával záródó szentélyből álló kápolna építési idejét a 13. század végére, esetleg a 14. század elejére datálta. Az egyik templom melletti sírban talált Szent István érem alapján, az eredeti, az alapítólevélben említett templom építését a Koppány leverése utáni térítéshez, a pusztulását a pogánylázadáshoz kötötte. Ugyanakkor 10. századi kerámiát is említ a területen, amely a korábban itt élökre utal. ${ }^{9}$

1973-ban jelent meg Szigetvári György Somogy megye építészei emlékeiről szóló könyve, amelyben a szerző az apátságot is bemutatta. A templom szerkezete kapcsán Zádor beszámolójának gondolatait ismétli meg. A hajó déli falán festésnyomokról, a korai faragványok mellett 14-16. századi, de 12-13. századi kövekről is írt. ${ }^{10} 1976$-ban, L. Szabó Tünde írt beszámolót a műemléki helyreállításról, amiben háromhajós, félköríves apszisos templomot említett. ${ }^{11}$

Az 1978-ban megjelent Árpád-kori kőfaragványok című kiállítás-katalógusban Nagy Emese ismét rövid összefoglalást adott a feltárás eredményeiröl. A templomról ezúttal kissé bővebben beszélt, alaprajzát a centrális és a hosszanti térelrendezés kombinációjaként jellemezte. Azt írta a félköríves szentélyű föhajóhoz keskeny oldalhajók, ezekhez kétoldalt, a hajók teljes hosszában karzatlépcső alapozások és egyéb választóelemek csatlakoztak. Az oszloplábazatok illetve alapozásaik közötti távolság egyenlőtlen. A középső négy, nagy, masszív alapozás szabályos négyszögben helyezkedik el. A belső tagolás alapján nyugati, északi és déli karzatot is feltételezett. Megemlítette, hogy a régi alapítólevélben szereplő templom nyomai az alapokban fellelhetőek voltak, de a templom nem rekonstruálható valamint, hogy az első kolostor kisebb, a templomhoz nem csatlakozó épület volt. ${ }^{12}$ Ugyanebben a kötetben Marosi Ernő írt tanulmányt az Árpád-kori építészet fejlődésről, ebben a templomot egykor valószínűleg oldalkarzatos, bizánci-jellegü épületnek említette. ${ }^{13}$

Az apátságról szóló következő hosszabb publikációt Magyar Kálmán írta a TKM kiskönyvtárban. Összefoglalta az apátság történetét, a műemlék-együttes ismertetésénél nagyrészt Nagy Emese és Zádor Mihály beszámolóját vette alapul. A kiadványsorozatban szokásos belső borítós alaprajz a Nagy Emese által közölt alaprajzon alapult, de már korszakok szerint volt színezve. A templom falai egységesen az 1060-as évekre voltak datálva, a keleti támpilléres falak a 15-16. századi megerősítésként voltak jelezve. ${ }^{14} \mathrm{Az}$ alaprajz felnagyított változata található évek óta a romterület bejáratánál. Kozák Károly a térség korai sokszögzáródású szentélyeit vizsgálta, aminek során a centrális kápolnát a 13 . századra datálta. ${ }^{15}$

\footnotetext{
$9 \quad$ Nagy 1973 335, 338

10 Szigetvári 1973. 10.

11 L. Szabó 1976. 166.

12 Nagy 1978. 91.

13 Marosi 1978. 18

14 Magyar 1981

15 Kozák 1984. 103
} 
Nagy Emese 1994-ben, a Pannonia Regia kötetben újra rövid ismertetőt adott a feltárás eredményiröl. Beszámolója a 78-as leírásra hasonlított, ugyanakkor néhány új elemmel is kiegészítette azt. A templombelsőt tartó 4-4 oszlopot említett, amelyek közül a középső négy alapozása mélyebb, szabályos négyszöget ad ki, ez kiemelt középtér létezésére utal. Úgy vélte a tempIom analógiáit bizánci területen kereshetjük. ${ }^{16}$ Nagyjából erre a beszámolóra támaszkodott a térség Árpádkori templom-építészetét összefoglaló Valter llona is. ${ }^{17}$

A bencés építészet bemutatása kapcsán röviden a szentjakabi templomra is kitért Marosi Ernő, aki keskeny oldalkarzatokkal kísért, centralizáló részt is tartalmazó hosszanti hajótérről írt. A lehetséges párhuzamokat a bizánci provinciális építészetben valószínüsítette. ${ }^{18}$

A Paradisum Plantavit kötetben Tóth Sándor mutatta be az épületet. A néhány oldalas tanulmány az egyik leghosszabb és legteljesebb ismertetés a templomról. A szerző centrális, bizáncias épületet képzelt el. Azt írta, nem rekonstruálhatóak a mellékhajókat a főhajótól elválasztó támsorok, hiszen a templom oldalsó részeit szélességük nagyobb részében falakkal rekesztették, ráadásul a támeszközök sem voltak egyformák. A négy mély oszloppár viszont nagyjából négyzetes felületet jelöl ki. A templom nyugati részén narthexet feltételezett, ezt nem számolva nagyjából négyzetes alaprajzú teret kapnánk. A négy mélyebb alapozást kisméretű középső kupolához kötötte. Így egy olyan kilenc-osztatú tér jönne létre, amelynek kereszt alakú terei kiemeltek. A nyugati lábazatok narthex és naos közötti árkádívet tartanának, míg a keleti in situ lábazatoknál a kupolatámasz és a keleti fal közét felezve, hosszanti ívet vehettek fel. A sarokterek karzatosak voltak. Két átalakításnyomot említett meg, amelyek utalhatnak a korai templomra, de tervmódosításra is. A szentélyben talált alapozásnyomok mellett, a déli oldalfalban lévő, részben egy lizéna sérülésében kibukkanó befalazott nyílást tartott ilyennek. 12-13. századra datálható építőtevékenységre utaló köveket - oszlopfö töredékét és talán kapubélletből származó fejezetfrízt - is említett. A kolostor alaprajzát 1400 körüli átépítés szokásos elrendezést mutató eredményének, a kis centrális kápolnát 13. századi építésűnek tartotta. ${ }^{19}$ Ugyanebben a kötetben az egyes bencés kolostorok történetét katalógusszerüen összefoglaló Hervay F. Levente egy apszissal, két keskeny oldalhajóval, nyugati karzattal, torony nélkül épült, majd többször átépített templomról írt. ${ }^{20}$

Viszonylag bő terjedelemben emlékezett meg a templomról a megye középkori egyházszervezetét vizsgáló M. Aradi Csilla is. Bazilikális, háromhajós elrendezésű templomként említette az épületet. Megállapította, hogy a háromhajós, félköríves apszisos és egyenes záródású mellékapszisos, a főhajótól néhol fallal elválasztott dongaboltozatos, keskeny mellékhajós épület

\footnotetext{
16 Nagy 1994.71-72.

17 Valter 2005. 56

18 Marosi 1996. 136.

19 Tóth 2001. 242-46.

20 Hervay 2001. 527
}

a hazai irodalomban analógia nélküli. Az elválasztó oszlopsorok alapozásának távolsága egyenlőtlen, az oldalhajókban karzatlépcsők voltak. A nyugati pillérek a kegyúri karzathoz, esetleg oldalkarzathoz tartozhattak. Úgy vélte a 14-15. század fordulóján történt a templom gótikus átépítése és a kolostorszárny teljes kiépítése. A templomban a pilléreket megvastagították, a szentélyben valamint a hajó nyugati valamint északi oldalán támpilléreket építettek. A korai templom kapcsán felvetette fatemplom lehetőségét is. ${ }^{21}$

A templomról szinte minden összefoglaló munkában megemlékeztek, de általában csak 1-2 bekezdést szenteltek neki. Wehli Tünde háromhajós, félköríves apszisos, karzatos templomot említett. ${ }^{22}$ Szakács Béla Zsolt centralizáló épületet képzelt el négy középpillérrel, középső toronnyal vagy kupolával. ${ }^{23}$ Marosi Ernő centrális jellegü alaprajzról írt is, oldalkarzatokat is említett. $^{24}$

A somogyi bencés templomokról írt tanulmányában Magyar Kálmán azt írta, a korai bazilika különlegességét a nyolc oszlop és a falakon lévő lizénák által lehatárolt terek adják. A templombelső közepén található „két-két négyzetes mélyített oszlop” egy keresztirányban húzódó tér négyzet alakú, valószínűleg kupolával fedett közepét határolják. Nyugaton nárthex-et és kegyúri karzathoz vezető lépcsőket, félkörívesen záródó főszentélyt, egyenes záródású mellékszentélyeket rekonstruált. ${ }^{25}$

Tóth Sándor a Magyar Múvelődéstörténeti Lexikon szerzetesi templomokról szóló szócikkében újra viszonylag bő terjedelemben írt a monostor templomáról, ekkor centrális térmaggal ellátott hosszanti elrendezést említett. Azt írta a centrális magot négy utólag lerakott pilléralap jelzi, amelyek között egybefüggő haránttérrel lehet számolni az oldalfalakig. Innen nyugatra és keletre téglalap alakú sarokterek voltak elrekesztve. A templom nyugati végén másik, talán karzatos elrendezésü haránttér helyezkedett el. ${ }^{26}$

Buzás Gergely centrális jellegü alaprajzú épületként, a királyi monostorok (Szekszárd, Feldebrő) kicsinyített másaként írta le az épületet. Toronypárral kombinált nyugati karzattal, a hosszház felett középtoronnyal számolt. Az apszis előtt diadalívet, itt és a szerzetesi kórus előtt rekesztőkorlátot, míg a mellékhajóban alacsony falazott emelvényeket, belső karzatokat rekonstruált. Az épület analógiáit az Adria középső vidékén, Közép-Itáliában és Dalmáciában találta meg ${ }^{27}$ Nyugati toronypáros, középtornyos, hosszanti felépítményű templom van ábrázolva a helyszíni kiállításban lévő, Gáspár András és Gáspár Boldizsár által 2010-ben készített maketten is. Ezen a keleti kolostorszárny nincs jelezve, az udvart és a kerengőfolyosót csak 3 oldalról veszik körbe épületek.

\footnotetext{
21 Aradi 2007. 99-101. és adattár

22 Wehli 2001

23 Szakács 2009. 39-40.

24 Marosi 2013. 111

25 Magyar 2012. 4-6.

26 Tóth 2011. 187-188

27 Buzás-Toth 2001. 66. Az emlitett Adria-vidéki analógiákról a szekszárdi apátság kapcsán ír bővebben: Buzás 2010. 262-264
} 
A megye erődített egyházi épületei bemutatásakor M. Aradi Csilla a 14-15. század fordulójához kötötte a kolostor megerődítését. Azt írta az ekkor kiépülő kolostorszárny nyugati részét - amely eredetileg az első periódusbeli kolostor kerítőfala lehetett - erős támpillérekkel erősítették meg, így védőfunkciót is betölthetett. Komolyabb erősítés a 16 . század elejére tehető, ekkor a monostor keleti zárófalán kívül külső téglafalat húztak, ekkortól datálható várfunkciója. ${ }^{28}$

$\mathrm{Az}$ irodalmat röviden áttekintve láthatjuk, hogy nemcsak a templom egyes részletei, de annak egész szerkezete, jellege is többféleképpen értelmezhető. Kiemelhetünk néhány folyamatosan visszatérő kérdést. Az egyik a mellékhajók pontos azonosítása. Ez a probléma már az első két publikációban, a feltáró régész és a helyreállítást végző építész írásaiban érzékelhető. Nagy Emesénél, majd másoknál is a mellékhajók és a főhajó közötti határt a pillérek alapozása jelezte, így a mellékhajóhoz csatlakozó vagy abban álló zárt karzatlépcsőkről, egyéb térelválasztókról írtak. Ezzel szemben Zádor Mihály, majd később többen ez utóbbi területeket tekintették mellékhajóknak és a belső alapozásokat pl. karzatot tartó pillérekhez kötik. Részben ehhez kapcsolódik az egyenlőtlen távolságra álló, különböző pilléralapozások problematikája. Azaz, hogy a teret három hajóra osztó egységes rendszer részeként lehet-e a 8 alapozást kezelni, vagy sem? Menynyire különül el a középső négy oszlop? Nagy Emese két párhuzamos, a templomot három hajóra osztó, 4-4 oszlopból álló sorként értelmezte ezeket, ugyanakkor felhívta a figyelmet különbözőségükre, négy középső által kiemelt középtérről írt. A kétféle alapozást funkcionálisan teljesen elkülönítve is kezelték, ebben az esetben a faragott oszloplábak diadalívhez illetve karzathoz kapcsolódnának és nem alkotnak egységes rendszert a négy középsővel.

Általában elfogadták az oldalsó - északi és déli - karzatok létét. Ezt az oldalsó zárt fülkékhez és a délnyugati lépcsőhöz kapcsolódva rekonstruálták. A nyugati faragott oszloplábakhoz kapcsolódva többször nyugati karzatot rekonstruáltak már, előfordul, hogy toronypárral is kombinálták, máskor viszont elhagyták és pl. narthexet is gondoltak helyére. A négy középső pilléralaphoz kapcsolódva többször gondoltak kis középső toronyra vagy kupolára, viszonylag ritkábban merült fel nyugati toronypár lehetősége. Utóbbi a közölt alaprajz hiányosságaival is magyarázható.

Mindezek meghatározzák a talán legfontosabb kérdést, az épület centralitását, és az ehhez többször kapcsolódó „bizánciasságot” illetve ennek mértékét. Ez Nagy Emese 73-as beszámolójában nem szerepelt, de 78-ban már a centrális és hosszanti elrendezés kombinációjáról írt. Az azóta megjelenő publikációkban bár vannak egyértelmüen a centrális vagy hosszanti jelleget hangsúlyozó írások - leggyakrabban centrális és hosszanti elemek valamilyen arányú együtteseként írták le az épületet.

A lehetséges párhuzamokat vizsgálva általában

28 Aradi 2013. 207. megemlítették, hogy az épület Magyarországon analógia nélküli, ugyanakkor gyakori a hasonló korú szekszárdi és feldebrői templomhoz való kapcsolása. Ezek kicsinyített másaként is említik, ilyenkor előbbiekhez hasonló, centrális alaprajzzal próbálták rekonstruálni. A távolabbi analógiákat kezdetben általában a bizánci birodalom különböző vidékein keresték, később részben az épület szekszárdi monostor templomával való összekapcsolása miatt is - Itália illetve az Adriai tenger középső vidékei felé is fordult a figyelem.

Az alapítólevélben szereplő korábbi templom nyomairól Nagy Emese is említést tesz. Mint láttuk ennek pontos korára az alapítólevélben nincs utalás, csak szerfelett régiségét említik. Nagy Emese és Győrffy György megállapításainak megfelelően általában a 11. századra, a Szent Istváni egyházszervezés időszakára datálják. A későbbi átépítések kapcsán - Nagy Emese megállapítását elfogadva - egy 14-15. századra keltezhető gótikus átépítést tartanak számon, ugyanakkor a szakirodalomban többször említést tesznek 12-13. századi kőanyagról is.

Talán a legfontosabb, hogy összességében a ma álló falakat szinte mindenki nagyrészt a 1060-as évekre keltezte és gyakorlatilag - kis átépítésekkel és átboltozással - egyidősnek gondolta.

\section{A feltárási dokumentáció tanulságai}

Nagy Emese ásatási dokumentációjában számos fontos, és a rövid publikációkban nem említett információ található. Úgy vélem ezek rövid ismertetése nagyban segítheti az egykori épület teljesebb megismerését.

\section{Szentély megemelés, egykori padlószintek}

Az ásatási beszámoló nem említi és a 60-as évekbeli helyreállításon sincs jelezve, hogy legalább kétfokos szentélylépcsőre és a szentélynek viszonylag jelentős megemelésére szereztek bizonyítékokat a feltárás során. A korábbi padlószintet a szentély lábazati magasságában találták meg, efölött volt a későbbi lépcső, amelynek 2. lépcsőfoka jelentősen magasabban volt a szentély előtt álló faragott oszloplábazatoknál. Nagy Emese a szentély megemelését a gótikus átépítéshez kapcsolta. (3-4. ábra)

A templomhajó valószínüsített padlószintje a 60 -as évekbeli feltáráson még érzékelhető volt, és az egykor ezen álló, szentélybe vezető lépcsőként használt római párkányt is megtalálták. Feltehetően nem csak az új, de a régi szentélymagasságnál is alacsonyabban volt. A feltárást vezető régész ezt a szintet gótikusnak nevezte, feltehetően mélyítéssel való kialakítását egy időre tette a szentély megemelésével.

\section{A faragott oszloplábazatok elfedése}

Az eredeti helyükön álló lábazatokat elfedve, téglával körülrakva találták meg. (5. ábra) Nagy Emese ezt is a gótikus átépítéshez kapcsolta, amikor a szentélyt, az új szentélylépcsőt is keretbe foglalva nyugat felé meghosszabbították. A délkeleti falban, a lábazat felett 


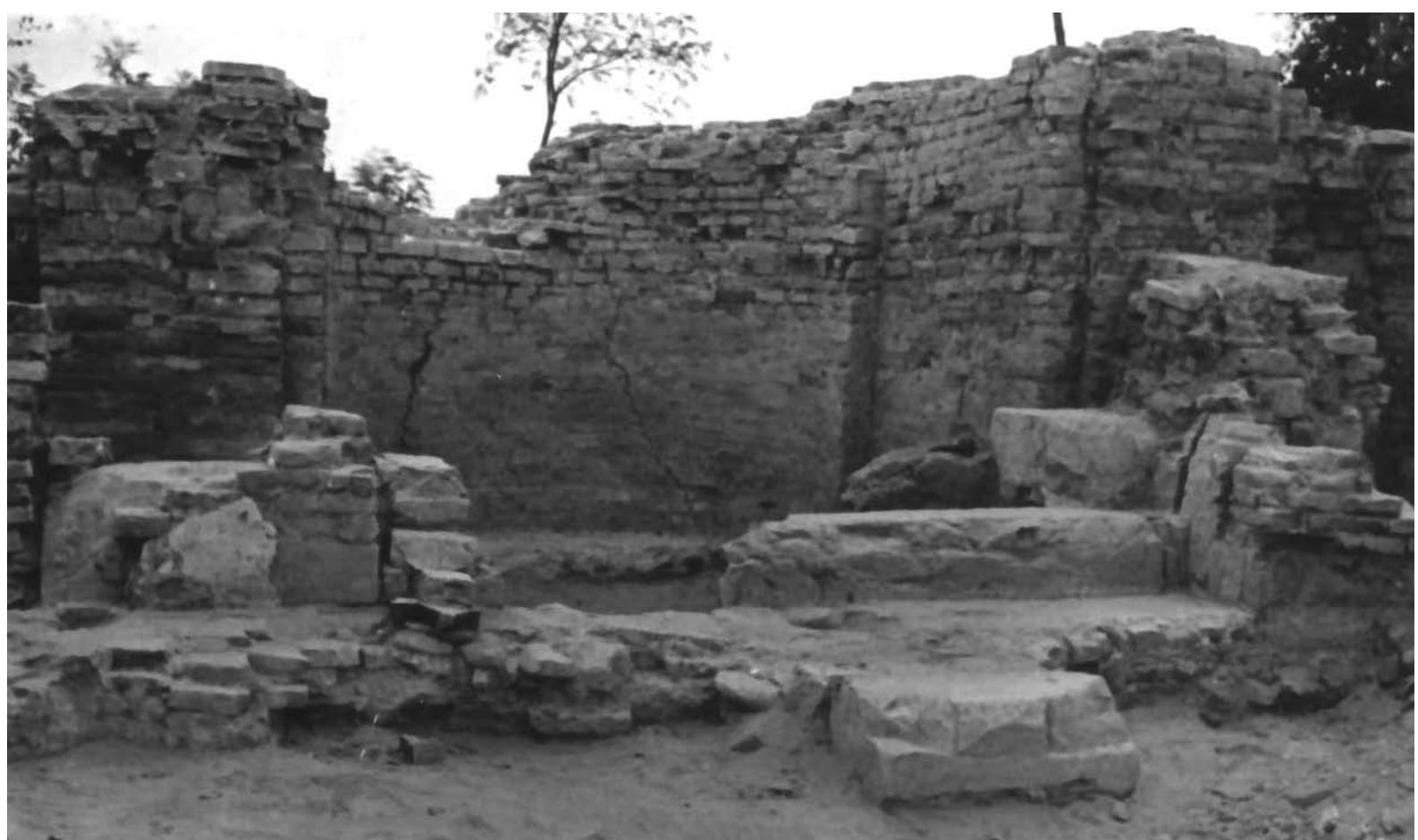

3. ábra: A szentély a szentélylépcsővel (Nagy Emese ásatási dokumentációjából)

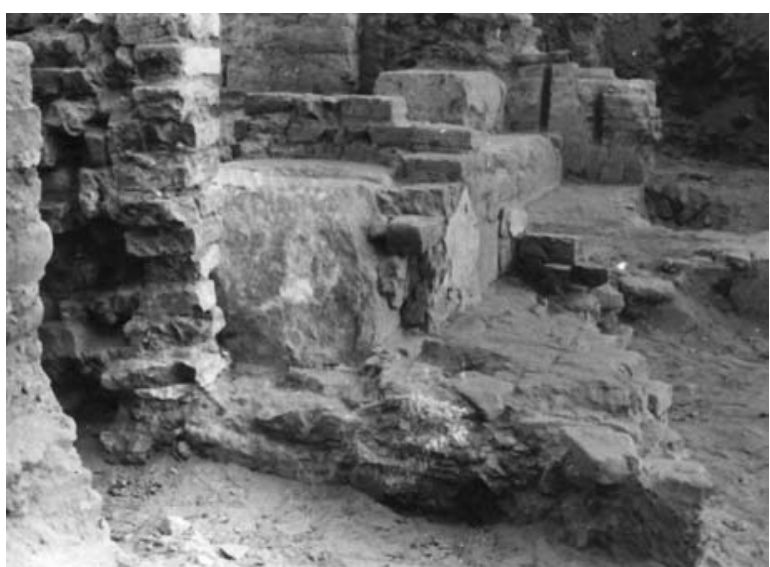

4. ábra: A szentélylépcső és a körbefalazott oszloplábazatok

(Nagy Emese ásatási dokumentációjából)

egy faragott oszloptörzs darabját bontották ki, amely a korabeli fotó alapján jól azonosítható a kiállított kőanyag egy publikált darabjával ${ }^{29} \mathrm{~A}$ fényképen, a lábazat fölötti téglákon látszik, hogy kerek, domború felületet vettek körül, a faragott oszlopláb a csavart oszloptörzset tartotta. (6. ábra) A szintén eredeti helyén talált északnyugati lábazat is téglával volt körülfalazva.

\section{A nagy pilléralapok késői elfedése}

A templom rekonstruálásakor kiemelt szerepet szoktak kapni a nagy, négyzetes alakú, egy négyzet

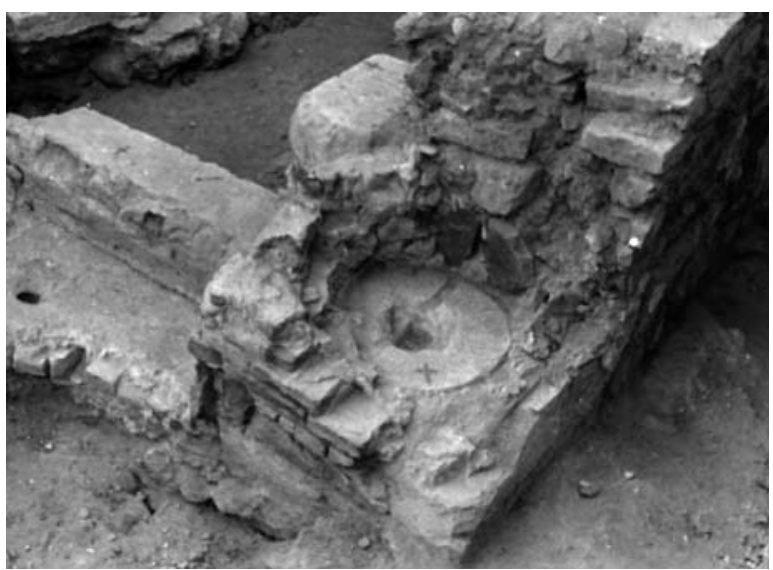

5. ábra: A szentély falainak nyugati irányú meghoszszabbitásakor körbefalazott DK-i oszlopláb (Nagy Emese ásatási dokumentációjából)

alakú teret kijelölő pillérek. A dokumentáció alapján úgy tünik ezeket közvetlenül a hajó egykori padlószintje alatt találták. A már említett gótikus átépítéshez kötött, a lépcsőnek használt római kő alatt lévő, téglatörmelékes szint fedte őket. Ebben az esetben a pillérek már nem álltak a templom késői periódusában, feltehetöen vissza is lettek bontva. (7. ábra)

Hasonló magasságig lehetett visszabontva és elfedve a nyugatabbi pilléralapok között húzódó, vékony és keskeny, $38 \mathrm{~cm}$ vastag, $15 \mathrm{~cm}$ magasságig megmaradt alapozás. Nagy Emese a pillérek közötti merevítönek írja le, megemlíti, hogy igen rossz állapotú. 


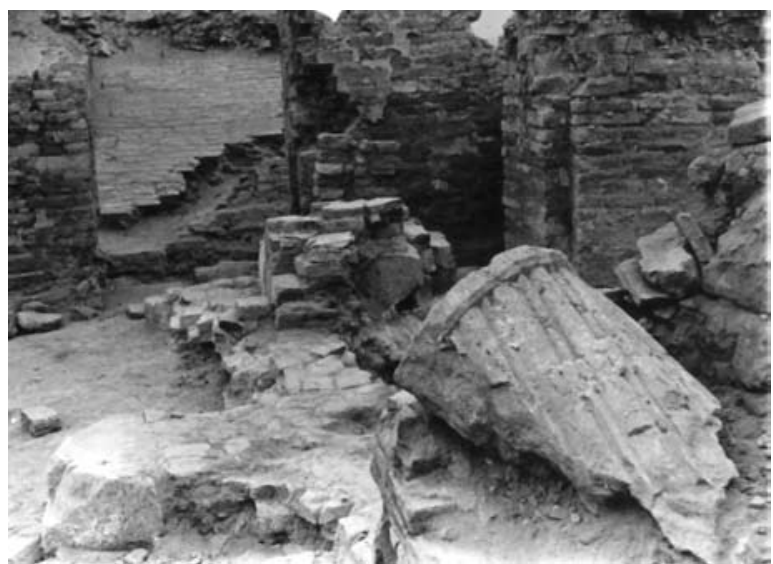

6. ábra: A körbefalazott oszloptörzs (Nagy Emese ásatási dokumentációjából)

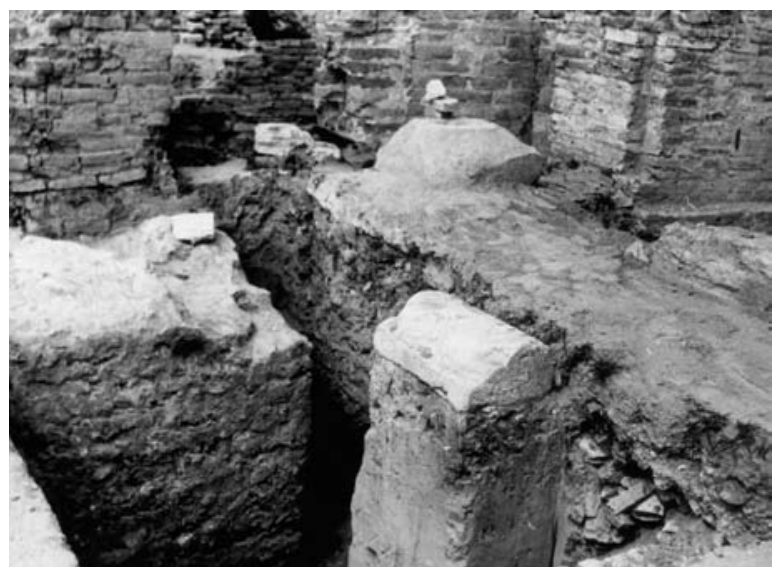

7. ábra: Az ÉK-i, nagy szögletes pilléralapozás (Nagy Emese ásatási dokumentációjából)

feltehetően a kapuból származható kőfaragványt „hengertagot, hornyolt, ornamentális faragványokat" - találtak.

Az ásatási naplóban Nagy Emese azt írta, hogy egy-egy nyugat-keleti irányú fal köti össze az egykori faragott lábazatokat a nyugati zárófallal, ezeket merevítő falakként határozta meg. Ugyanakkor az ásatási dokumentációban lévő alaprajzokon látszik, hogy nyugatra, keletre is be vannak kötve (11. ábra). Az így kialakuló téglalapok a müemléki helyreállításon ábrázolva vannak, de a megjelent alaprajzról hiányoznak. Felmenő falak nem álltak már itt, de az észak-déli irányú falakra rálógtak a még álló nyugat-keleti irányú belső falak.

\section{Külső falak}

1960-as években egy vastag kőfalat találtak a nyugati templomfal előtt. Ennek folytatása a nyugati kolostorszárny nyugati fala előtt is látszott. A pontosan nem ismert korú és funkciójú fal iránya eltér a templométól, azzal szöget zár be. Az erősen lejtő dombon viszonylag alacsony volt, feltehetően a jelenlegi betonozott járda alá esik egy része. (9. és 11. ábra)

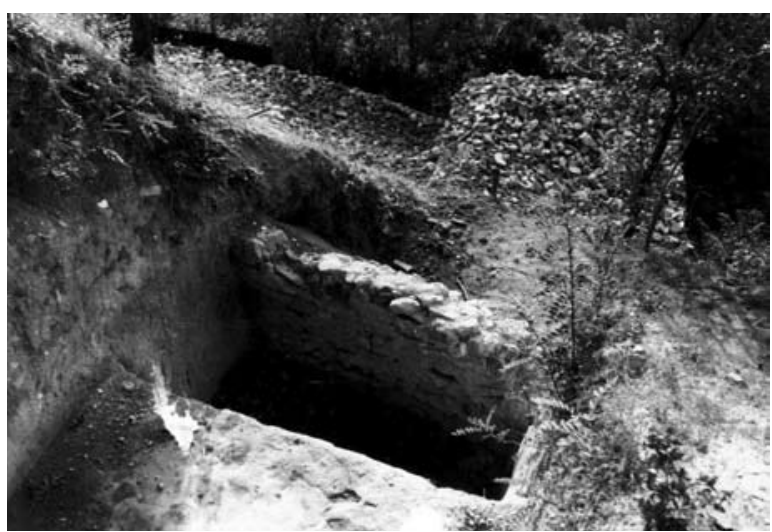

9. ábra: A templomtól nyugatra lévő fal

(Nagy Emese ásatási dokumentációjából) 


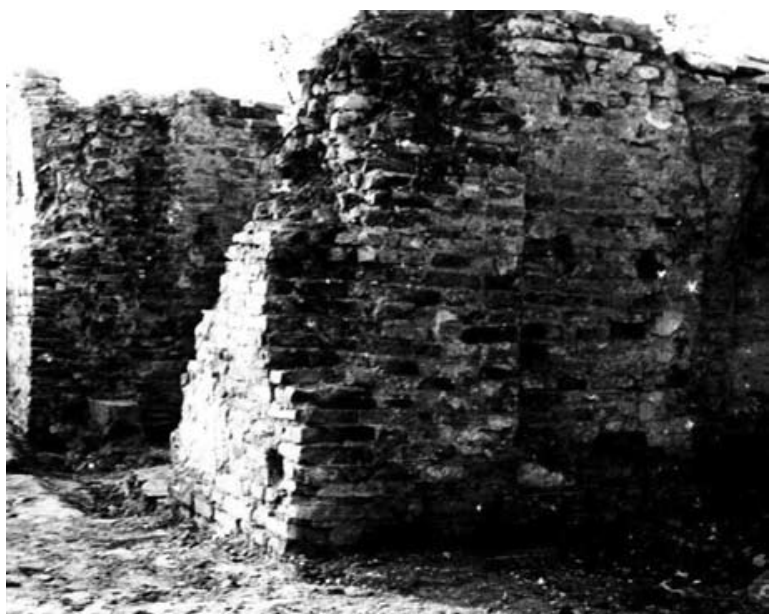

10. ábra: A templom délkeleti sarkától induló fal, rajta boltozat indítása

(Nagy Emese ásatási dokumentációjából)

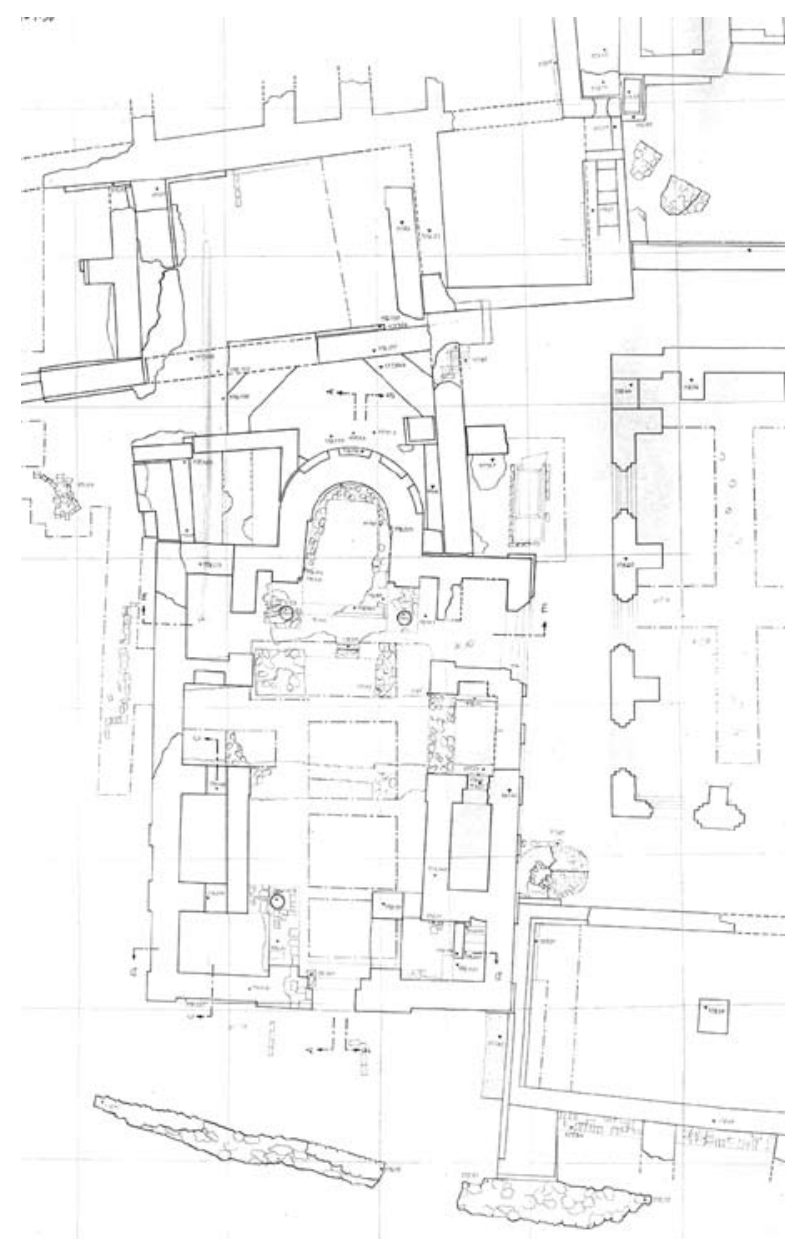

\section{A szentélytöl keletre lévő falak}

A templom délkeleti részéhez épített nyugat-keleti irányú fal csatlakozásánál boltozat indításának nyomát találták. Ez ma már kevésbé látszik, a korabeli fotón jobban kivehető. Ez a fal jóval bentebb, északabbra van a kerengő feltételezhető vonalánál, egy helyiség maradványa lehet. (10. ábra) Egy 1964-ben közölt alaprajzon jelezték ennek feltételezett vonalát, egy itt megtalált magasan falazott téglasír köré valószínűsítve, sírkápolnaszerüen rekonstruálva azt. (11. ábra) Az említett sír sajnos üres volt, egy kő sírlappal zártak le. A fal folytatásában egy lépcsőt tártak fel.

A szentélytől keletre lévő területen egy helyiség falait találták meg, aminek a belső, szentély felőli falán letaposott sárgásbarna földet, késői járószintet észleltek. Ez alapján már nem állt a fal a legkésőbbi időszakban. A falhoz csatlakozó két ferde falat dokumentálták, de funkcióját nem tudták meghatározni. 2014-ben ezeken a területeken is feltárást végeztünk, így Nagy Emese megállapításait több ponton ki tudtuk egészíteni.

\section{Rajzok a dokumentációból}

Úgy vélem érdemes néhány rajzot közölni az egykori dokumentációból. Mint utaltam rá, a megjelent alaprajz hiányos, jóval használhatóbb egy 1964-ben készült összesítő. (11. ábra) Ezen nem szerepel a 66-os feltárás eredménye (hasonló összesítőt abból az évből nem találtam), úgy tűnik kisebb pontatlanságai vannak de így is igen fontos információkat tartalmaz. Itt az alapokban is szereplő falak is látszanak és jól követhető a fentebb említett jelenségek jó része. A templom nyugati részen jól látszik, hogy az alapozások a sarkokban két téglalapot adnak ki, amelyek feltehetően torony alapozásaként meghatározhatóak. Megfigyelhető, ahogy a szentély előtt lévő faragott oszlopok keleti irányú alapfalakkal csatlakoznak a szentély falaihoz, köztük látható a szentélylépcső maradványa is. Szerepelnek a templomtól keletre, délkeletre valamint a szentélytől északra elhelyezkedő „sekrestyében” lévő meglehetősen kusza falak, alapozások, a templomtól délkeletre lévő kőlappal zárt sír helye és a templomtól nyugatra lévő falak is.

Úgy vélem szintén nagyon fontos két 1961-ben készült rajz. (12. kép) Feltehetően a templom középvonalában állva készültek. Sajnos az alapozások általában nem láthatóak rajta, de így is igen hasznosak, még a helyreállítás előtti állapotot ábrázolják. A falak megtalálásuk magasságában, ráépítés, helyreállítás nélkül látszanak. A köztük lévő betöltés már el van hordva, ekkor már feltárták a templom egykor föld felett álló részét. 

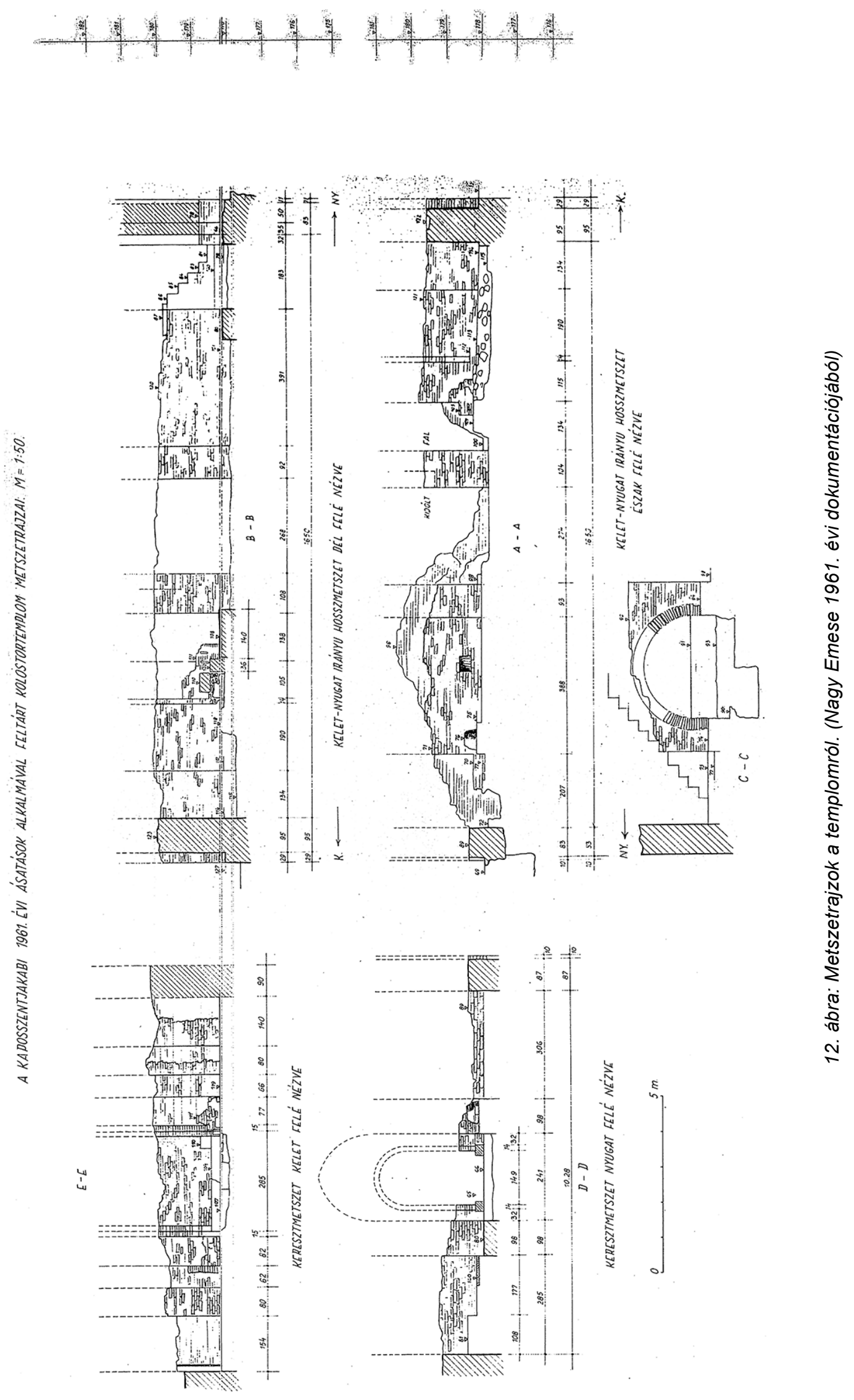


\section{Rövid összefoglalás a 2013-2014. évi munkákról}

Az elmúlt évtizedekben a helyreállított romterület állapota - elsősorban az apátsági templomnál és környezetében - erősen leromlott, bizonyos helyeken életveszélyessé vált, feltétlenül felújításra és részleges átalakításra szorult. Szerencsére a munka megkezdése előtt hitelesítő feltárásokat folytathatunk a területen. ${ }^{30}$

Egy rövidebb, 2013 őszén végzett ásatás után, 2014 április-májusában végeztük el a munka nagyobb részét. Gyakorlatilag a templom egész területét, valamint egy, a templom szentélytől délkeletre lévő, kisebb területet sikerült (újra) feltárnunk. A legfontosabb célunk a még feltáratlan részek kibontása mellett az alapozások dokumentálása és ennek segítségével a különböző korú falak - lehetőség szerinti - elkülönítése volt.

Az 1960-as évekbeli visszatöltés alatt gyakorlatilag mindenhol találtunk valamennyi nem kibontott réteget, objektumot. Azt tapasztaltuk, változó, nagyjából 40 és $200 \mathrm{~cm}$ közötti mélységben ástak le a jelenlegi felszín alá, így helyenként elérték a bolygatatlan sárga altalajt, máshol akár 1-2 méteres feltáratlan részek is maradtak. Összesen 50 sírt bontottunk ki, nagyjából 60 $\mathrm{db}$ (föleg római) pénzt és számos kisleletet találtunk, számos őskori objektum is előkerült. Ezeknél is fontosabb, hogy a templom szerkezetére, építési periódusaira is értékes adatokat szereztünk.

Talán legfontosabb eredményünk, hogy megtaláltuk az alapítólevélben említett, alapítás előtti templom maradványait. Az épület sekély, nagy kőtömbökből álló alapozását főleg az apátsági templom belső falainál tudtuk végig követni. Utóbbi szentélyének falain belül előkerült a korai épület négyzetes apszisának alapozása. A keleti, déli, északi és két rövid szakaszon (a későbbi templom belsejébe került) nyugati fal alapjának nyomát is megtaláltuk. (13-15. ábra) A templom egyenes szentélyzáródású, nagyjából 12-13 m hoszszú, 7,5 m széles épület volt. A római téglából készült lábazatából és felmenő falaiból is komoly szakaszok azonosíthatóak, úgy tűnik az apátsági templom építésekor felhasználták ezeket. (19. ábra) Utóbbinak szélessége és hossza is nagyobb volt, a régi templomot szinte körbevette, így annak maradványai csak az északi és déli részen lévő, zárt helyiségek közepéig tartottak. Ezeken a falakon látszik is itt egy elválás, a templom külső falainak külső oldalain lizénák jelzik ezt a vonalat. (15. ábra) Amennyire a ráépítésektől megállapítható, ezek a falak $80-85 \mathrm{~cm}$ szélesek voltak.

A templomtól keletre feltárt területen a korai időszakhoz köthető megerősítés egyértelmű nyomait fedeztük fel. Egy igen mély árkot találtunk itt, amelynek a természetesen feltöltődött részében hullámvonalkö-

30 A kaposvári Rippl-Rónai Múzeum által folytatott, a cikk szerzője által vezetett feltáráson a múzeum dolgozói közül Nyári Zsolt, Cserép Tamás és Stunya Péter vett részt. Rajtuk kívül Aradi Csilla segítségét szeretném megköszönni. A felújítás és így az ásatás költségeit a Nemzeti Kulturális Alap és Kaposvár Megyei Jogú Város Önkormányzata fedezte. Köszönetet szeretnék mondani a hitelesítő feltáráshoz ragaszkodó Dr. Mezős Tamás építésznek, valamint $L$. Balogh Krisztina városi főépítésznek is. teg-díszes kerámia volt. Az árok belső oldalán cölöpök sorakoztak. A 60-as évekbeli dokumentáció egy fotója alapján, ezek eredetileg legalább két sorban helyezkedhettetek el. Akkor egy magasabban és a templomhoz közelebb elhelyezkedő cölöpsor több cölöplyukát tárták fel, bár pontos funkciójukat nem tudták meghatározni. Az egykor lejtősebb domboldalon mélyebben fekvő, árok felőli, keleti sorig - úgy tűnik - már nem ástak le, ennek cölöphelyeiböl nekünk sikerült $5 \mathrm{db}$-ot feltárnunk. Az árkot, a rajta futó későbbi falak miatt, mi sem tudtuk teljesen kiásni, de így is 3,5-4 méter mélyen követtük a jelenlegi felszíntől. (16. ábra) Mivel a területen bronzkori telep objektumai is feltárásra kerültek, elképzelhető, hogy egy korábbi árkot használtak fel, újítottak meg a középkorban. Az erődítés nagyobb területet védett, a templom mellett más épületeket is körbefoghatott. Jelen ismereteink szerint az erődítés és a korai templom összetartozását valószínűsíthetjük. Úgy vélem az árok legkésőbb az apátsági templom építése után nem sokkal, de inkább annak építése előtt betemetődhetett. Részben természetesen töltődött fel, de felső részét és a felette lévő területet törmelékes réteggel egyengették el, egyenesebb felületet alakítva így ki. Ezt a munkát talán az apátság alapításához kapcsolhatjuk.

Az új, 18,5×12,5 méteres apátsági templom építéséhez felhasználták a korábbi templom maradványait. Az ekkor készülő falak alapozása jól elkülöníthető. A mélyebb és szélesebb (kb. $130 \mathrm{~cm}$ mélységü, 98$110 \mathrm{~cm}$ széles) alapok rendszertelenül bedobált, habarccsal leöntött tégla és kődarabokból állnak, amiket a lábazatnál ferde vagy egyenes téglasorral zárnak le. Ezt találjuk a romjaiban ma is látható félköríves szentélynél és nagyjából mindenhol a templom külső falainál. (19. ábra) A nyugati oldalon, a kapunál az ilyen alapozások két torony vonalát rajzolják ki. A nyugati oszloplábak is ezen, a toronypárhoz tartozó alapon vannak. Több ilyen falak által metszett sírt találtunk (15. ábra). Hasonló alapozást találunk a szentély előtt lévő - feltehetően diadalívhez kapcsolható - faragott oszloplábak alatt is. (14. ábra) Ezek $160 \mathrm{~cm}$ széles alapon állnak. Közöttük és a szentélyfal alapozása között kis rés van, utóbbinál picivel sekélyebbek és talán valamivel szabályosabban rakottak is, de alapozásuk alapvetően azonos, a kis eltérések talán az építés folyamatával magyarázhatóak.

Arról, hogy a templom közepén lévő, valamiféle középteret kijelölö, nagy pilléralapok melyik periódushoz tartoznak, reményeink szerint a habarcsvizsgálatok adhatnak majd információt. Ezek igen nagy méretüek, közel két méter mélyek - komoly tartófunkciójuk lehetett. (17. ábra) Igen jó minőségű munkának tűnnek: szépen sorokba rakott, habarccsal összefogott, leöntött, egyenesre, szabályosra vágott kövekből állnak. A mi általunk feltárt részen nem vágtak semmit. A korainak templom falaihoz épültek szorosan viszont az apátsági templom É-D-i irányú belső falai ezekhez futnak. A nyugatabbra lévők között sekély alapozás fut, ezt talán kórusrekesztőhöz kapcsolhatjuk. 


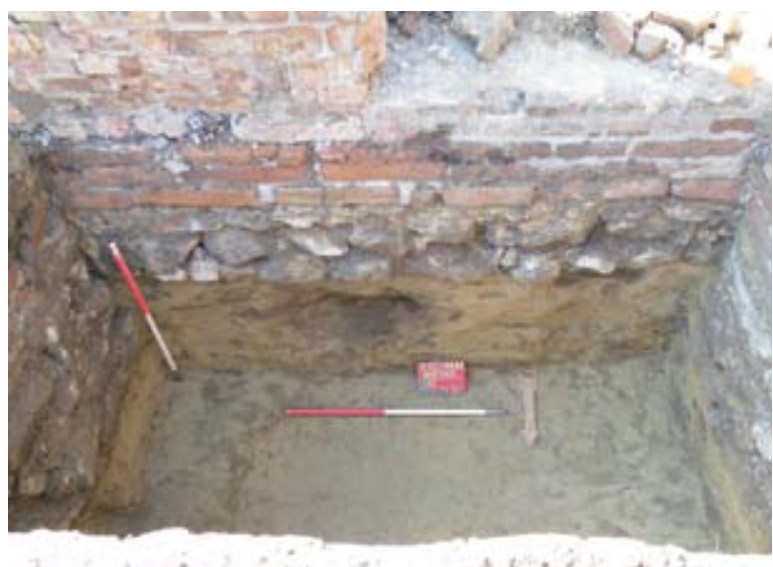

13. ábra: A korai templom maradványai

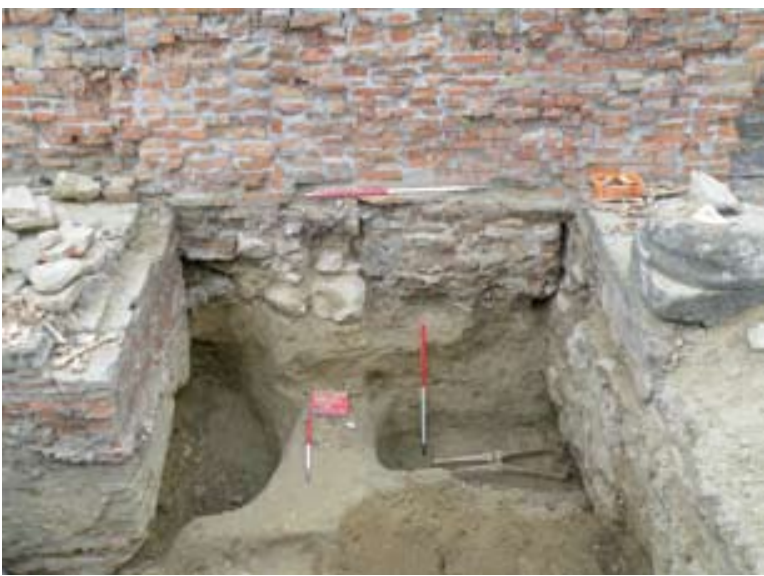

15. ábra: 3 periódus falainak találkozása. Balra a korai templom nyugati vége, jobbra a délnyugati torony belső fala. A kettő között a legkésőbbi hozzáépítés.

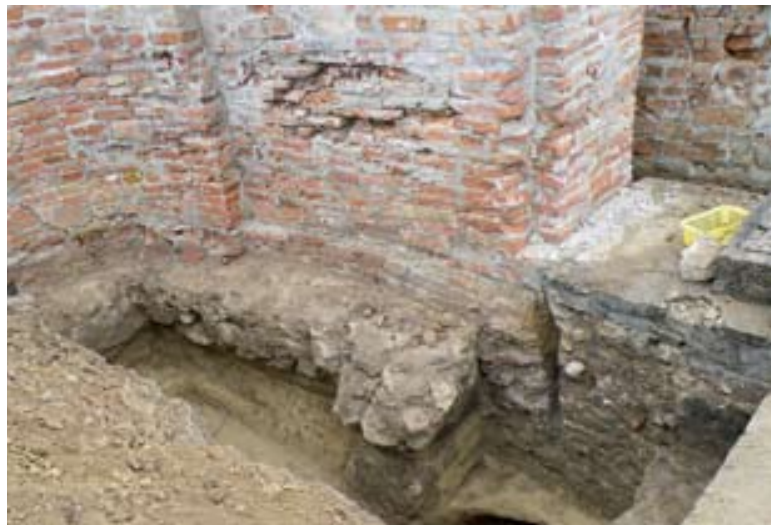

14. ábra: A korai templom négyszögletes apszisának alapozása a későbbi félköríves szentély belsejében

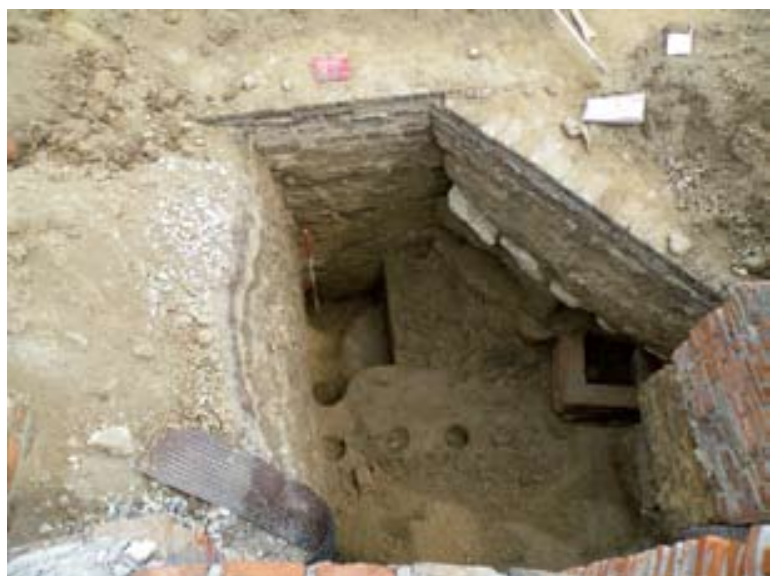

16. ábra: A nagyméretü árok, a ráásott sírral és falakkal (a templom szentélyéröl fotózva)

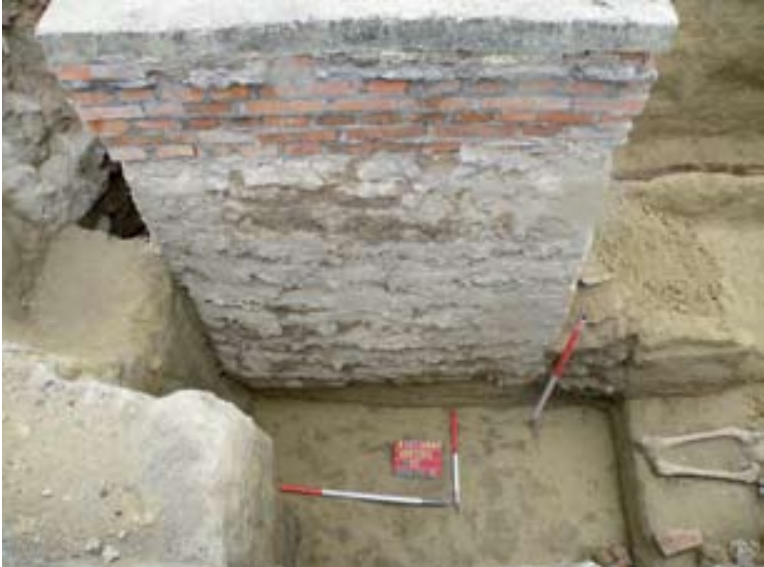

17. ábra: A középső, nagy pilléralapozások egyike (a felső része újkori hozzáépítés)

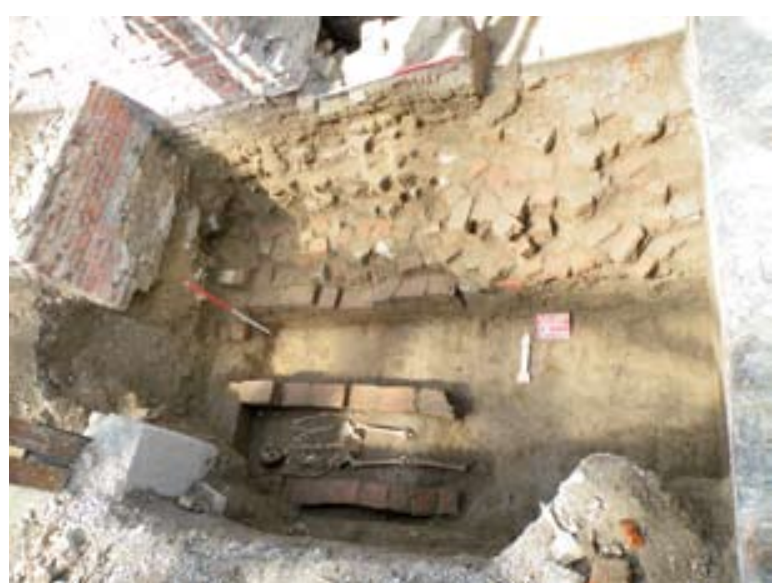

18. ábra: Falazott sírok maradványai, egyiket a ráásott kolostori épület alapozása rombolta 


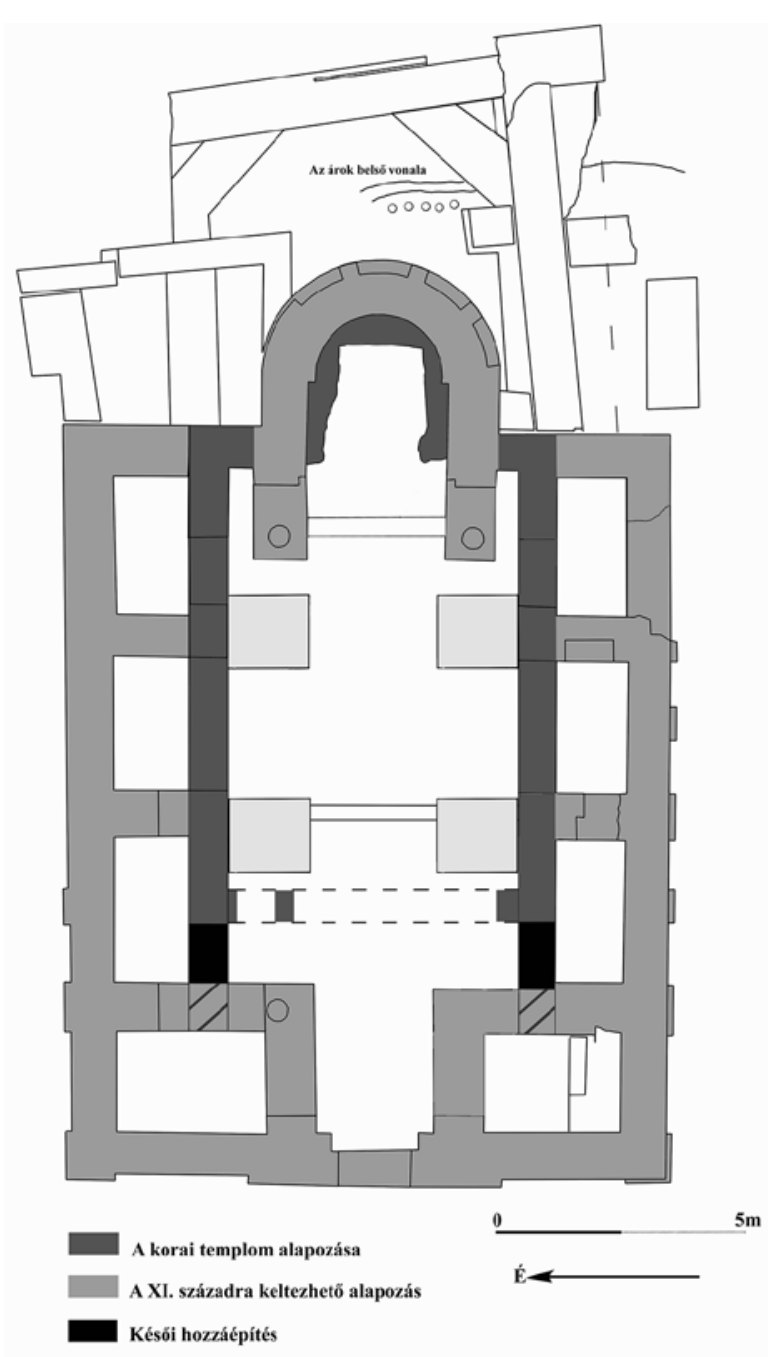

19. ábra: A templom azonositott építési periódusai. Nagy Emese 1964-es térképének felhasználásával

Az 1060-as években épült templomot később, újabb falszakaszokat építve átalakították. A tornyok és az alapításkor itt álló templomhoz kapcsolható, sekélyebben alapozott falak között - tehát az általában karzathoz kapcsolódva értelmezett, északi és déli zárt helyiségek belső falának nyugati részén - későbbi, sekély, habarcsba rakott téglából álló alapozások vannak. (15. ábra) Tehát csak későn alakultak ki a templom északi és déli falánál lévő zárt fülkék, a tornyok eredetileg nem kapcsolódtak a tőlük keletre lévő belső falakhoz. Ezeket később húzták el a tornyokig, azokba bekötve, talán azokat is átalakítva. Elképzelhető, hogy ez az átalakítás a boltozáshoz kapcsolódik és így a 15. század legelejére lehetne tenni.

A templomtól délkeletre nyitott kis szelvényünkben - részben az erre az időszakra már betemetett árkot metsző - sorokba rendeződő falazott sírokat, illetve ezek maradványait találtuk. Ezeket az apátság alapítása utáni időszakra tehetjük. Két ilyen sírt rombolt egy agyagba rakott téglából álló, széles alapozás. (18. ábra) Az alapozás részleteit az 1960-as években megtalálták, de - mivel nem tárták fel teljes mélységig a területet - nem tudták eredeti vonalát, funkcióját azonosítani. Ekkor már csak az alapozás nyugati részén állt egy az alapnál jóval keskenyebb fal, ennek és a templom keleti falának találkozásánál a 60-as években még jól látszott az egykori boltozat indítása (10. ábra). A helyiséget ekkor kisebbnek gondolták, most sikerült megállapítanunk, hogy egy, a templomhoz később de feltehetően még az Árpád-korban - hozzátoldott épület alapozása fut itt, amely keleten a domb aljától induló, Nagy Emese által pinceként meghatározott, boltozatos helyiséghez csatlakozik. Jól érzékelhetően annak faláig tart, egy épületsort alkothattak, a déli fala valahol a mostani kerengő északi szárnyának déli falánál lehetett. A 14-15. század fordulóján kiépülő gótikus kolostornál jóval korábbi épületről van szó, hiszen, legkésőbb ez utóbbi megépülésekor, ezt már jórészt el kellett bontani. Feltételezhetjük, hogy a „pince” is hasonló korú. A fal elbontása után, több temetkezés is rombolta az alapozás maradványait.

A templom szentélyétől keletre a müemléki helyreállítás is jelez alapozásokat, amelyekről valószínüsíthetjük, hogy egy megkezdett, de nem befejezett poligonális szentély építéshez kapcsolódnak. A szentélyalapozás keleti fala egyenlöre nincs azonosítva, az északkeleti, délkeleti illetve északi falának alapja van meg. Délnyugaton feltehetően a fentebb említett, agyagba rakott téglával alapozott épület falát használták volna. A tervezett szentély alapjait metszette egy fal, ami a templomtól keletre lévő, valamikor a késő középkorban, a kerengővel együtt vagy annál később kialakított helyiséghez tartozik. Legkésőbb ekkor bontják el az agyagba rakott téglákkal alapozott helyiség északi falának keleti részét. Az 1960-as években az alapozáson egy lépcső maradványát találták meg, valamilyen bejárat lett kialakítva itt, amely a kerengőbe vezetett.

Megállapítottuk, hogy a templom szentélyétől északra lévő, sekrestyeként azonosított épület késői, a 14-15. századnál nem korábbi kialakítású. A falak alatt hétfajta alapozást találtunk, amelyek nem is mindig a felettük lévő falakkal egykorúak, az épületrész külső környezetének újra megásásáig nem értelmezhetőek. $A z$ mindenesetre biztos, hogy a helyiség közepén a megkezdett, de nem megépített, gótikus szentély fala fut, amit vágnak a helyiség külső falai.

Reményeink szerint a leletanyag feldolgozása során ismereteinket tovább bővíthetjük. Abban is bízunk, hogy a romterület folyamatos átalakításához, helyreállításához kapcsolódóan módunk lesz további feltárások végzésére. 


\section{Irodalom}

M. Aradi Cs. 2007: Somogy Megye Árpád-kori és középkori egyházszervezetének létrejötte és megszilárdulása. (Doktori Phd. Diszszertáció)

M. ARADI Cs. 2013: Erődített középkori kolostorok és templomok kutatása Somogy megyében. A Kaposvári Rippl-Rónai Múzeum közleményei. 01: 203-216.

BÁRDOS E. 1978: Középkori templom és temető Kaposvár határában. Somogyi Múzeumok Közleményei 3. (1978.) 187-234.

BÁRDos E. 1987: Középkori templom és temető Kaposvár határában II. Somogyi Múzeumok Közleményei 8. (1987.) 6-82.

BuzÁs G. és Tóth E. 2001: Magyar Építészet. A romaiaktól a román korig. Budapest. 2001.

BuzÁs G. 2010: A szekszárdi apátság temploma a középkorban. In.: Kollár T. (szerk.): Építészet a középkori Dél-Magyarországon. 555-603.

GYÖRFFY GY. 1975: Kaposvár az Árpád-korban. In.: Kanyar József (szerk.): Kaposvár. Várostörténeti tanulmányok. Kaposvár 1975. 63-73.

Hervay F. L. 2001: Bencések és apátságaik a középkori Magyarországon. In.: Takács Imre (szerk.): Paradisum Plantavit. Bencés monostorok a középkori Magyarországon. Kiállítási katalógus. Pannonhalma, Bencés Főapátság. 461-567.

KомјÁtHy M. 1975: A középkorvégi Kaposvár. In.: Kanyar József (Szerk.): Kaposvár. Várostörténeti tanulmányok. Kaposvár 1975. 75-92.

KumORovitz L. B. 1964: A Zselincszentjakabi alapítólevél 1061-böl. Tanulmányok Budapest Múltjából XVI. Budapest. 1964. 43-83.

Magyar K. 1981: Kaposszentjakab. Bencés apátság romjai. Tájak, Korok, Múzeumok Kiskönyvtára, 68. Bp. 1981

MAGYAR K. 2012: A bencés rend középkori somogyi egyházai nyomában 2. Somogyi honismeret. 2012. 1-2.

MARosı E. 1978: Árpád-kori Kőfaragványok - Árpád-kori építészeti fejlődés. In.: Tóth Melinda - Marosi Ernő: Árpád-kori kőfaragványok. Székesfehérvár. A Székesfehérvári István Király Múzeum Közleményei D sorozat 121. sz. Székesfehérvár. 15-28.

MARosı E. 1996: Bencés Építészet az Árpád-kori Magyarországon. A rendi építőiskolák problémája. In.: Takács Imre (szerk.) Mons Sacer 996-1996. I. 130-142
MAROsı E. 2013: Romanika Magyarországon. Budapest.

NAGY E. 1973: Előzetes Jelentés a kaposszentjakabi ásatásról. Somogyi Múzeumok Közleményei. 1. (1973.) 335-339.

NAGY E. 1978: Kaposszentjakab. In.: Tóth Melinda - Marosi Ernő: Árpád-kori kőfaragványok. Székesfehérvár. A Székesfehérvár István király Múzeum Közleményei D sorozat 121. sz. Székesfehérvár. 1978. 91-92

NAGY E. 1994: Zselicszentjakab. In.: Mikó árpád - Takács Imre (Szerk.): Pannonia regia. Művészet a Dunántúlon. Budapest. 1994. 71-72.

L. SzABó T. 1973: A kaposszentjakabi bencés apátság müemléki helyreállítása. Műemlékvédelem. 1976/3. 165-8.

SzAKÁcs B. Zs. 2009: Román kori művészet. In.: Bellák - Jernyei Kiss - Keserű - Mikó - Szakács Béla Zsolt: Magyar művészet. A művészet története 16. Budapest. 24-43.

SzIgetVÁRI GY. 1973: Építészeti emlékek Somogyban. 1973. Kaposvár

То́тн S. 2001: Zselincszentjakab. In.: Takács Imre (szerk.): Paradisum Plantavit. Bencés monostorok a középkori Magyarországon. Kiállítási katalógus. Pannonhalma, Bencés Főapátság. 2001. 342-346

То́тн S. 2001a: A 11-12. századi Magyarország Benedek-rendi templomainak maradványai. In.: Takács Imre (szerk.): Paradisum Plantavit. Bencés monostorok a középkori Magyarországon. Kiállítási katalógus. Pannonhalma, Bencés Főapátság. 2001. 229-266.

То́тн S. 2011: Szerzetesi templomok. In.: Köszeghy Péter (főszerk.) Magyar Művelődéstörténeti Lexikon. Középkor és kora újkor. XI Budapest. 186-199.

VALTER I. 2005: Árpád-kori téglatemplomok a Nyugat-Dunántúlon METEM Könyvek 43. Budapest.

WEHLI T. 2001: Művészet a Honfoglalástól 1241-ig. In.: Galovics Géza - Marosi Ernő - Mikó Árpád - Wehli Tünde: Magyar művészet a kezdetektöl 1800-ig. Budapest 2001. 9-91.

ZÁDOR M. 1964: Kaposvár. Budapest. 1964. 


\title{
Research in the area of the Benedictine abbey, Kaposszentjakab Part 1.
}

\author{
ISTVÁN MOLNÁR
}

The monastery, previously named Zseliszentjakab, founded in 1061 is the first private founded monastery in Hungary. The excavations, led by Emese Nagy, took place between 1960-1966. The church reconstruction with its special form was a source of a long-time dispute between scholars. These interpretations can be supported by the presentation of unpublished photos, sketches and statements of the archaeological documentation.
During 2013-14 we reexcavated the territory of the monastic church. We successfully discovered the first period church with a single nave and a rectangular apse built prior to the foundation of the abbey. The monastic basilica with three circular apses and twin western towers was built with the incorporation of this church. The basilica was later altered during the Gothic period, when it received vaulting. 